\title{
EFFECTIVENESS OF COVER CROPS FOR WATER POLLUTANT REDUCTION FROM AGRICULTURAL AREAS
}

\author{
Reid Christianson ${ }^{1, *}$, Jordan Fox ${ }^{2}$, Neely Law ${ }^{2}$, Carol Wong² \\ ${ }^{1}$ University of Illinois Urbana-Champaign, Urbana, Illinois, USA. \\ ${ }^{2}$ Center for Watershed Protection, Inc., Ellicott City, Maryland, USA. \\ *Correspondence: reiddc@illinois.edu.
}

\section{HighLIGHTS \\ - Nitrogen loss reduction due to a cover crop tends to improve with increased cover crop biomass production. \\ - Mixed phosphorus loss reduction results in cold climates where freeze-thaw cycles occur and can increase dissolved phosphorus losses. \\ - Cereal rye was the primary cover crop studied and tended to provide the most water quality benefits.}

\begin{abstract}
Mitigating nutrient losses from agricultural fields retains these nutrients for subsequent crop production and reduces the risk to downstream water quality. This study evaluated the impact of cover crops, as part of an annual cropping system, on reducing nutrient losses and enhancing water quality. Cover crop literature focusing on water quality was reviewed to determine important factors regarding cover crop performance and cost. Results show that a grass-based cover crop and mixes with grasses tend to increase nitrate loss reduction (40\%) compared to legumes (negligible). Biomass growth was also important, with early seeding or growth of a cover crop in areas with increased growing degree days enhancing performance. For phosphorus loss, benefits did not necessarily increase with increasing biomass. Further, dissolved phosphorus concentrations may increase due to freeze-thaw cycles (23\%), although overall dissolved phosphorus losses tend to decrease due to less runoff (34\%). Cover crop implementation costs ranged from a savings of $\$ 25$ to $\$ 44 \mathrm{ha}^{-1}$ year-1 before soybeans and corn, respectively, when implementing a cover crop for five straight years to a cost of $\$ 193 \mathrm{ha}^{-1}$ year-1. Including a cover crop in annual crop rotations with adequate time in the fall for germination and growth can reduce nitrogen and phosphorus losses from production agriculture to help meet water quality goals across the U.S.
\end{abstract}

Keywords. Catch crop, Nitrogen, NRCS, Phosphorus, Practice Code 340, USDA, Water quality.

$\mathrm{T}$ his article is part of a collection that provides a comprehensive review and evaluation of the performance and cost-effectiveness of selected agricultural conservation practices on nutrient and sediment loss reduction.

A cover crop in an agricultural setting provides growing ground cover during periods of the year when primary crops are not active. Historic uses in agriculture include soybean trials (Voorhees, 1915) and orchard establishment (Oskamp, 1920 ) in the early 1900s. There was a gradual rise in cover crop literature through the 1980s and then a sharp increase in available literature in the 1990s, with Google Scholar results for "cover crop" more than tripling during this time. Discussions surrounding water quality enhancements associated with cover crops have been a topic since at least the 1960s, with cover crops being used to prevent erosion

Submitted for review on 1 April 2020 as manuscript number NRES 14028; approved for publication as an Invited Review Article and as part of the Agricultural Conservation Practice Effectiveness Collection by the Natural Resources \& Environmental Systems Community of ASABE on 24 February 2021.
(Bullard, 1966). Today, there is a nationally recognized cover crop standard developed by the USDA, Conservation Practice Standard 340 (USDA-NRCS, 2014), which defines a cover crop as "grasses, legumes, and forbs planted for seasonal vegetative cover." Further, this standard lists an explicit purpose of a cover crop as "reduce water quality degradation by using excessive soil nutrients." This national standard is supported by state-specific standards, which provide additional detail and guidance on successful cover crop management strategies.

Typically, cover crops are implemented in row crop agriculture where the primary crop is harvested in the fall, and a field is fallow over the winter period. Based on the USDA Census of Agriculture, cover crops are used across the country, with Texas, Iowa, and Indiana having the most cover crop area (fig. 1a) (USDA-NASS, 2017), although six of the top ten states are in the U.S. Midwest. These six states are also member states of the Mississippi River/Gulf of Mexico Watershed Nutrient Task Force (Hypoxia Task Force, 2017). The highest concentration of cover crops is in the northeast (fig. 1b), and three of the top ten most densely cover-cropped states are in the Chesapeake Bay watershed. Connecticut has 


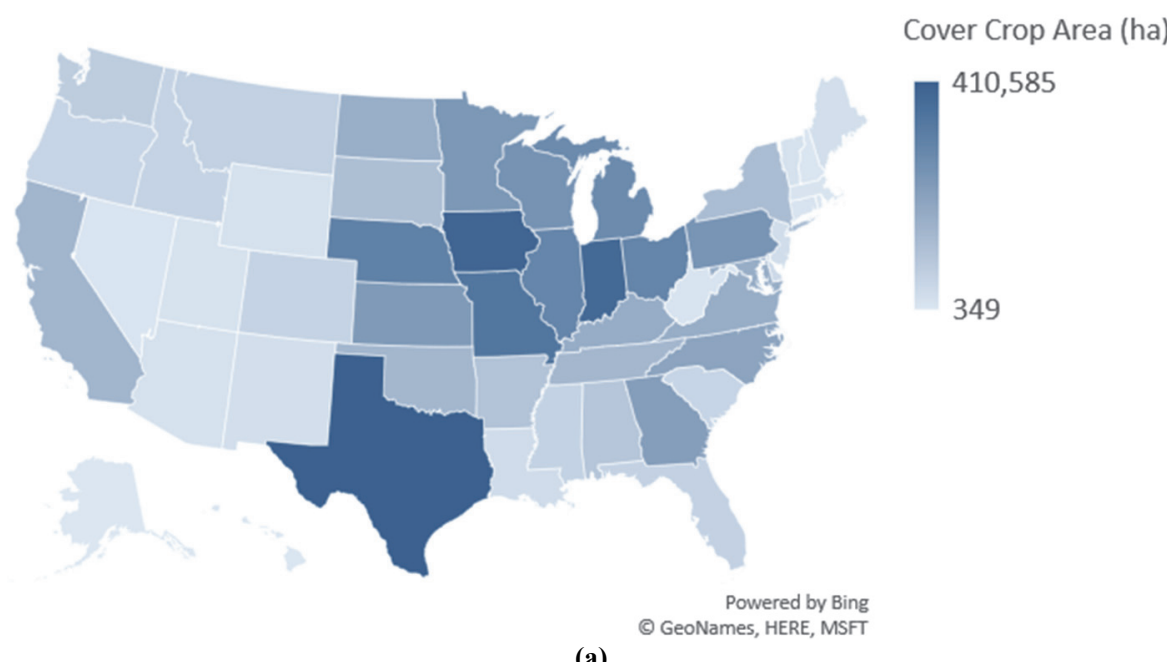

(a)

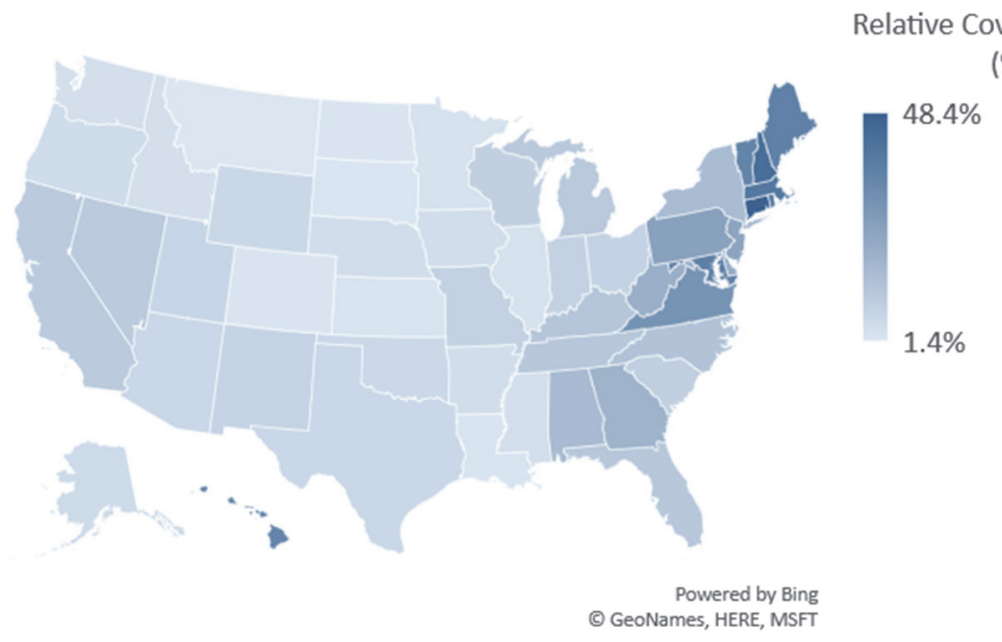

(\%)

(b)

Figure 1. Cover crop estimates from the 2017 USDA Census of Agriculture (USDA-NASS, 2017) excluding areas enrolled in the Conservation Reserve Program (CRP): (a) cover crop area in hectares and (b) relative amount of cover crops, using the sum of no-till, reduced till, and intense till area as a proxy for maximum suitable cover crop area.

the highest cover crop density at $48 \%$ of tilled land, compared to a national average of $5.5 \%$. Little information is available on historic cover crop implementation across the country. However, between 2012 and 2017, national implementation increased by over two million hectares, from just over four million hectares to just over six million hectares (USDA-NASS, 2017).

There are many initiatives across the U.S. to improve water quality, with recent efforts focusing on the Mississippi River basin and the Chesapeake Bay watershed. Efforts in both of these watersheds have started to quantify the specific water quality benefits of cover crops. These two efforts provide a substantial body of knowledge on the impact of cover crops on water quality. With the use of cover crops increasing across the country, it is essential to holistically quantify these and other benefits associated with the practice.

Despite the importance of cover crops for meeting water quality goals, much of the emphasis on cover crops comes from a soil health focus. Increases in soil organic matter (SOM) and other enhanced soil characteristics, such as fertility and soil structure, have been found with long-term use of cover crops (Abdollahi and Munkholm, 2014; Dabney et al., 2001; Ding et al., 2006; MCCC, 2014; White et al., 2016). Increasing SOM also positively impacts soil hydraulic characteristics (Saxton and Rawls, 2006) across all soil types. These changes to soil characteristics are tangible and are likely why the link between cover crops and soil health is strong. The ability to couple water quality benefits to a practice being adopted primarily for soil health purposes (CTIC, 2017) allows grower-focused discussions, with water quality as a side benefit. This approach enables adoption to continue to escalate without changing messaging but still allows estimation of water quality benefits.

The overall objective of this study is to improve understanding of cover crop processes, nutrient removal effectiveness, and cost-effectiveness. Specifically, this review aims to (1) compare, integrate, and synthesize results from reviewed studies conducted in different experimental settings and site conditions to obtain a systematic understanding of the mitigation efficacy of this conservation practice; (2) obtain general insights from the reviewed studies on the performance-based costs of this conservation practice; (3) develop recommendations for cost-effective conservation practices to be considered for prioritization when funding 
agencies are developing their programs; and (4) collect defensible scientific data to support and update the technical content in the USDA-NRCS Conservation Practice Standards and to help agencies and organizations document the magnitude of the nutrient loss reduction efforts in an area of interest.

\section{Performance Assessment}

The initial surge in cover crop literature in the 1990s has been outshone by a three-fold increase in literature since 2000, based on Google Scholar "cover crop" search results. As such, much of the literature reviewed was published since 2000, although these articles often include data from the 1990s. To align with the NRCS Conservation Practice Standard, the focus was placed on work done in the U.S. However, the reviewed meta-analyses often included international studies. Initial literature searches included online search engines and university library queries. Reference tracing of initial articles helped to finalize available sources. More than 40 sources were reviewed; however, only 20 sources reporting annual water quality impacts are included as site-year data in the Supplemental Material (available at https://doi.org/10.13031/14519094.v1). Much of the included information is more representative of northern climates. Further, to date, the majority of water quality research has used over-wintering cereal rye as the primary cover crop, although the use of other species and mixes is rapidly increasing (CTIC, 2017).

Of the 20 studies included in the Supplemental Material, 14 provided annual data (one or more years) for concentrations and/or losses of nitrate, phosphate, or a measure of sediment or erosion. Most included direct measures of water quality, although potentially leachable nitrate from soil sample analysis was represented as an annual value in one study. Eleven studies reported nitrate, three reported phosphate, and five reported a measure of sediment or erosion. Of the 14 studies providing annual data, seven were published after 2000 , five were published in the 1990s, and two were published in the 1980s. Four of the seven studies published before 2000 focused on sediment loss or erosion and often included impacts of tillage. Effectiveness was determined by comparing the study control to the cover crop treatment for each site-year for which data were available. Results from previous reviews were not included in the assessment, although these sources were referenced and provided substantial content for discussion.

Several large-scale efforts have quantified cover crop performance for nutrient loss reductions. These include the Chesapeake Bay Watershed Model, the Chesapeake Bay Program's Expert Panel process, and nutrient strategies from several states in the Mississippi River basin, including Arkansas, Illinois, Iowa, and Minnesota. These efforts have relied on literature as well as expert opinion to constrain effectiveness values while providing long-term average performance for cover crops. Cover crop effectiveness has also been included in many general water quality or watershed models (CAST, 2017; Stroud Water Research Center, 2020; Tetra Tech, 2018). These models are informed by literature and published empirical relationships focusing on soil protection from rainfall, reducing velocities of overland flow, as well as scavenging and storing nitrogen as organic matter.

Due to its over-wintering characteristics, substantial biomass production, and ability to immobilize inorganic nitrogen (Meisinger et al., 1991; Shipley et al., 1992), cereal rye has been a common cover crop choice (MCCC, 2014). Although cereal rye is still a popular choice, cover crop mixtures with several species are on the rise (CTIC, 2017) and show promise (Finney et al., 2016; Kaye et al., 2019). Increased biomass production is key when considering longterm soil health impacts by increasing soil organic matter (Snapp et al., 2005) and shifting the carbon to nitrogen ratio (Al-Kaisi et al., 2005). Further, because cover crops reduce erosion during surface runoff (Alliaume et al., 2014; De Baets et al., 2011; Sojka et al., 1984), losses of organic matter and nutrients are reduced. Earlier work on cover crops highlighted the importance of many factors on biomass production. These included available growing degree days (location and dates of planting and termination), available nitrogen, type of cover crop, and seeding density (Brinsfield and Staver, 1991; Dabney et al., 2001; Meisinger et al., 1991; Shipley et al., 1992), which newer work continues to echo.

Kaspar et al. (2008) provided a useful example to illustrate the importance of biomass production in which cereal rye provided higher nitrate-nitrogen (nitrate-N) loss reductions in warmer climates (95\% in Kentucky) than in colder climates (13\% in Minnesota). The Minnesota nutrient strategy (MPCA, 2014) also highlights the biomass component, with a nitrate-N loss reduction of $10 \%$ for a cover crop after long-season crops like corn and soybeans and 50\% after short-season crops like winter wheat. Because grass-based cover crops scavenge nitrogen (Snapp et al., 2005), high biomass production indicates more nitrogen immobilized by the plants (Kuo and Sainju, 1998; Meisinger et al., 1991; Prabhakara et al., 2015).

In addition to biomass production, identifying the landscape (tile-drained versus non-tile-drained) and distinguishing between cover crop types (such as grasses, legumes, brassicas, or mixes) are critical to understanding how these cover crops impact water quality. Landscape and cover crop type information helps to identify nutrient loss pathways. For example, nutrient loss in tile-drained landscapes is dominated by nitrate- $\mathrm{N}$, whereas total phosphorus loss is the dominant factor in non-tile-drained landscapes (Christianson et al., 2018). As another example, grasses may provide enhanced nutrient loss reduction compared to legumes (CAST, 2017; Meisinger et al., 1991; Thapa et al., 2018). Kaspar et al. (2003) found that the presence or absence of a tile drainage system can also impact nutrient delivery. Tile drainage systems respond quickly (in one year or less) to management changes such as nitrogen application rates (Kaspar et al., 2003). Nutrient delivery in non-tile-drained systems can take several years (Staver and Brinsfield, 1998).

Because biomass production is critical to cover crop nitrate-N loss reduction, nuanced growing conditions unique to each study potentially add substantial variability to the results. With this in mind, considering the long-term average annual nutrient loss reductions provides an appropriate 
mechanism for evaluation. Future research to evaluate cover crop performance as a function of biomass would allow the application of methods using satellite imagery to estimate biomass (Hagen et al., 2016; Hively et al., 2009; Prabhakara et al., 2015) for more spatially explicit estimates of nitrogen and phosphorus loss reduction. Projecting annual performance based on planting date would also be helpful, as Thapa et al. (2018) showed that less nitrate leaching occurred when cover crops were planted early (August), with decreasing benefits as the planting date moved later into November. Thapa et al. (2018) also noted a decrease in cover crop nitrate loss performance as relative rainfall increased. The concept of using models to estimate the water quality benefits of a cover crop is not new. Dabney et al. (2001) suggested that "computer models are promising tools," and many models were initially developed in the 1990s.

Much of the water quality work done on cover crops evaluates nitrate- $\mathrm{N}$ as the primary nitrogen species impacting water quality from many heavily modified agricultural landscapes. There is a mix of research on water quality impacts at many temporal and spatial scales, from individual storms to annual effects, as well as modeling work. All of these assessments are informative and appropriate. However, longterm annual nutrient loss reductions are essential when tracking and planning the impact of cover crop implementation over large geographic areas. Further, because all landscapes are different, and the potential nitrate-N loss (per area) or the total load may vary substantially, considering the impacts of cover crops in a relative manner (i.e., percent loss reduction) is helpful when considering performance trends and comparing studies.

\section{NitRATE-NitRogen}

In Maryland, grass biomass production between 1,800 and 4,000 $\mathrm{kg} \mathrm{ha}^{-1}$ was linked to nitrate-N leaching loss reductions of about $80 \%$ when compared to fallow land using lysimeters (Staver and Brinsfield, 1998). Similarly, a study on potentially leachable soil nitrate-N in Pennsylvania by Finney et al. (2016) found a nitrate-N loss reduction of $90 \%$ with grass biomass of $8,500 \mathrm{~kg} \mathrm{ha}^{-1}$, with a nitrogen retention plateau occurring at just under $7,000 \mathrm{~kg} \mathrm{ha}^{-1}$. A meta-analysis by Thapa et al. (2018) showed similar results, with peak leaching loss reduction efficiency occurring at about $6,000 \mathrm{~kg} \mathrm{ha}^{-1}$. Although Thapa et al. (2018) noted a peak, the data showed a rapid increase in nitrate loss reduction up to a shoot biomass of about $3,000 \mathrm{~kg} \mathrm{ha}^{-1}$ and then a leveling off at about a $70 \%$ nitrate loss reduction. These studies represent the potential for nitrogen immobilization into biomass, limiting the risk of loss to the environment. In Washington State, biomass production of grass and grass-legume mixtures showed five-year average biomass production between 1,500 and 2,500 $\mathrm{kg} \mathrm{ha}^{-1}$ (Kuo et al., 2001). Further, that study identified reductions in nitrate- $\mathrm{N}$ leaching concentration between $37 \%$ and $84 \%$ during the highest reduction year of the five-year study (Kuo et al., 2001). When evaluating site-year data from reviewed literature containing water quality data, a similar response to no-legume biomass was observed, although the amount of scatter in these data clearly indicated that other factors are important (fig. 2).

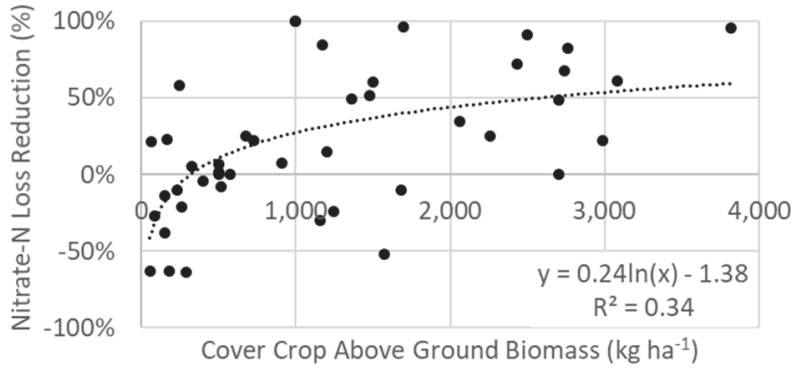

Figure 2. Nitrate-N loss reduction efficiency correlated with grass cover crop biomass production, including all U.S. studies reporting both nitrate-N losses in water and cover crop biomass production (number of observations $=44$ ). Data from the study site-years with references and additional details are provided in the Supplemental Material.

A meta-analysis by Valkama et al. (2015) evaluating several studies in Nordic countries showed a nitrate-N loss reduction of 50\% for grasses and other non-legumes but found no impact on nitrate-N leaching when using legumes as a cover crop. Similarly, a meta-analysis by Tonitto et al. (2006) focusing on USDA Hardiness Zones 4 to 6 showed an average nitrate-N leaching reduction of $70 \%$ for non-legume cover crops when non-legume cover crops were compared to an over-winter fallow field. Although their analysis indicated that a legume cover crop may provide about $60 \%$ of the nitrate leaching benefits of a non-legume cover crop, Tonitto et al. (2006) noted the need for further long-term research due to the complexities of mineralization and immobilization in highly managed systems. Finally, a comprehensive and global review by Thapa et al. (2018) found that neither legumes nor mixes had a significant impact on nitrate leaching, while non-legumes provided an average nitrate leaching reduction of $56 \%$.

Focusing on literature from the U.S., nitrate-N loss reductions between $0 \%$ and nearly $60 \%$ due to cover crop implementation have been found in tile-drained landscapes. A tile drainage study in Iowa by Kaspar et al. (2007) found a 59\% reduction in nitrate-N loss with a corn and soybean rotation. Interestingly, an Iowa State University report by Pederson et al. (2014) found differences between nitrate-N loss reductions in the soybean $(45 \%)$ and corn $(22 \%)$ phases of the common corn and soybean rotation grown in tile-drained landscapes. Another Iowa State University report found a $25 \%$ concentration reduction in nitrate- $\mathrm{N}$ loss (Helmers and Crumpton, 2015). Dougherty et al. (2020) used a cereal rye cover crop combined with no-till in Iowa. They found lower effectiveness of cover crops, with a 30\% reduction in nitrate concentration, but only a negligible reduction in nitrate loss due to increased annual drainage (Dougherty et al., 2020). The increase in drainage may have been due to the no-till treatment, as the authors found increased drainage in the other no-till treatment. Dougherty et al. (2020) also reported low biomass production, with an eight-year average of just $608 \mathrm{~kg} \mathrm{ha}^{-1}$. Similarly, Qi et al. (2011) found no significant nitrate- $\mathrm{N}$ loss reduction associated with a rye cover crop and subsequent corn or soybean production over a four-year study in Iowa, with average biomass production of $410 \mathrm{~kg}$ $\mathrm{ha}^{-1}$ and 1,630 $\mathrm{kg} \mathrm{ha}^{-1}$, respectively. Qi et al. (2011) provided a discussion of these results in comparison to Kaspar et al. (2007), which entailed differences in control plot nitrate-N 
concentrations, fertilization rate to corn, planting date, tillage, and rainfall patterns between the two studies.

In Arkansas, a two-year surface runoff study with cotton by Aryal et al. (2018) showed an $86 \%$ reduction in nitrate-N leaving the fields using an oat or wheat cover crop. Nitrate$\mathrm{N}$ was a small proportion of the influencing nitrogen leaving the fields (5\% to $30 \%)$ in that study. Although that study did not measure a cumulative annual impact, it reported performance during monitored storms over the study period.

Further, a review by Kaspar and Singer (2011) showed a broad range of performance, ranging from $6 \%$ to $94 \%$ reduction in leaching. The range was attributed to cover crop species, how much growth occurred, and how much soil nitrogen was removed by those crops. The authors discussed the dynamics of the nitrogen cycle, and they highlighted the influence of cover crops on the soil nitrate pool as well as the soil water reservoir.

Combining all non-legume studies done in the U.S. (detailed in the Supplemental Material), along with the latitude of the research location, resulted in a rough correlation, with decreasing nitrate loss reductions in more northern latitudes (fig. 3). This is likely a combined impact of latitude and study type because sites in more northern latitudes typically had tile drainage. When evaluating all site-year data, tile drainage systems generally showed lower nitrate-N loss reductions $(12 \%)$ than natural rainfall studies that measured runoff and surface drainage studies that measured nitrate in lysimeters or monitoring wells (43\%). This difference was statistically significant ( $\mathrm{t}$-test assuming equal variances with $\alpha=0.05$ ). However, it is unclear if this difference was due to the monitoring technique or to the specific landscape and cropping system.

Another observation was the strong relationship between reduction in nitrate- $\mathrm{N}$ concentration and reduction in nitrate$\mathrm{N}$ loss (fig. 4a) for all cover crops. This relationship had a slope near one, indicating that a reduction in nitrate- $\mathrm{N}$ concentration is likely the primary reduction mechanism, generally. Evaluating all water quality data for a non-legume cover crop from studies in the U.S. showed a median nitrate$\mathrm{N}$ loss reduction of $36 \%$, with a mean of $40 \%$ (see the Supplemental Material for more detailed information on siteyears) when using study treatment averages. In contrast to study treatment averages, evaluating site-year data for a nonlegume cover crop lowered the median and mean nitrate-N

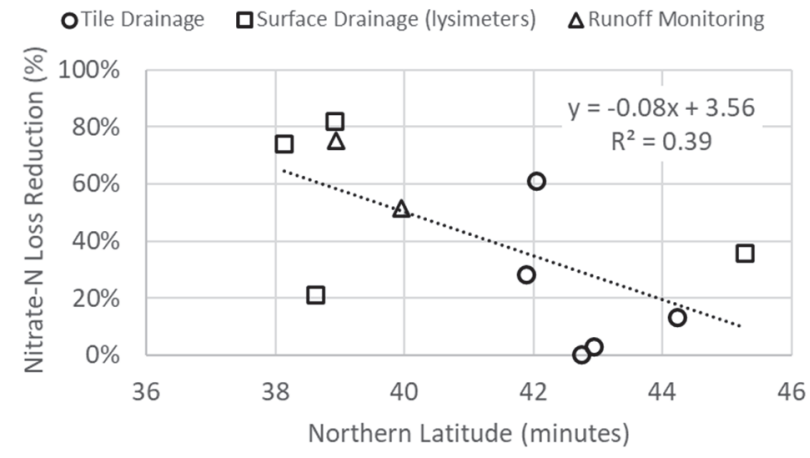

Figure 3. Nitrate-N loss reduction efficiency correlated with latitude in the U.S. Ten data points were included for grass cover crops and one for a mix with grass. Data from the study averages with references and additional details are provided in the Supplemental Material. loss reduction to $29 \%$ due to a larger number of site-years from lower-performing studies (fig. 4b). In other words, considering study averages equalizes the weight of each study, regardless of how many data collection years were included in the study. Mean nitrate- $\mathrm{N}$ concentration reduction $(36 \%$ in fig. 4b) was not significantly different from nitrate-N loss reduction for a non-legume cover crop ( $\mathrm{t}$-test assuming equal variances at $\alpha=0.05$ ).

\section{Total Nitrogen}

Work done in the Chesapeake Bay region provides a comparison of different cover crop types along with early and "average" planting time categories (CAST, 2017). Increasing the cover crop growing season to accumulate more biomass in an average weather year accounted for a 3\% increase in nitrogen loss reduction efficiency for cereal rye, general grass, and mixes with grass. Early planting times (before crops are typically harvested in the fall) provided $37 \%, 29 \%$, and $20 \%$ nitrogen loss reduction compared to "average" planting times of $34 \%, 25 \%$, and $17 \%$ for cereal rye, general grass, and mixes with grass, respectively. Legumes provide roughly a sixth (about 5\%) of the nitrogen loss reduction benefits of cereal rye. These estimates from the Chesapeake Bay Expert Panel process were the only source of information distinguishing between different types of cover crops for total nitrogen loss reduction and are summarized in figure 5 .

\section{Dissolved PhOSPHORUS}

Few studies reported phosphorus losses from treatments with a cover crop on an annual basis, although many included rainfall simulations or selected natural rainfall events. This gap in research has previously been noted by the Iowa Nutrient Reduction Strategy (IDALS/IDNR/ISU, 2016). Dissolved phosphorus can be elevated in cold climates due to freeze-thaw cycles and breakdown of plant tissues. This has been thoroughly studied in a review by Liu et al. (2019), which details the fractionation of phosphorus. Results from Liu et al. (2019) showed increases in dissolved phosphorus with harsh freezing and multiple freeze-thaw cycles with cover crop treatments. Liu et al. (2019) also noted relatively less movement of dissolved phosphorus in field settings when compared to laboratory studies, making soils and transport mechanisms in the field setting an important component of phosphorus movement. Significant differences between control and cover crop treatments were found for runoff volume, although there were no significant differences in dissolved phosphorus or total phosphorus loss.

In tile-drained studies, there were no significant differences in dissolved phosphorus leaching out of the topsoil or at the tile drain depth. However, individual studies have reported loss reductions. For example, available event data over a two-year study in Arkansas showed a 53\% reduction in runoff phosphate loss with an oat or wheat cover crop planted in late October or early November and terminated in early or mid-April (Aryal et al., 2018). In that study, phosphate made up between $20 \%$ and $60 \%$ of total phosphorus. An annual study by Daigh et al. (2015) also showed substantial reductions in subsurface drainage phosphorus concentration and loss in Iowa comparing continuous corn with and without a cereal rye cover crop. The four-year mean 


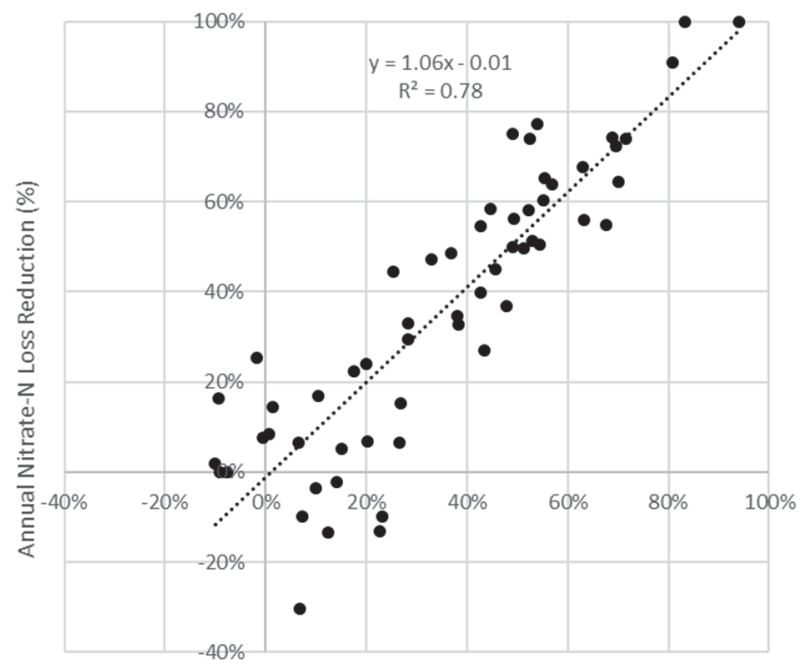

Nitrate-N Concentration Reduction (\%)

(a)

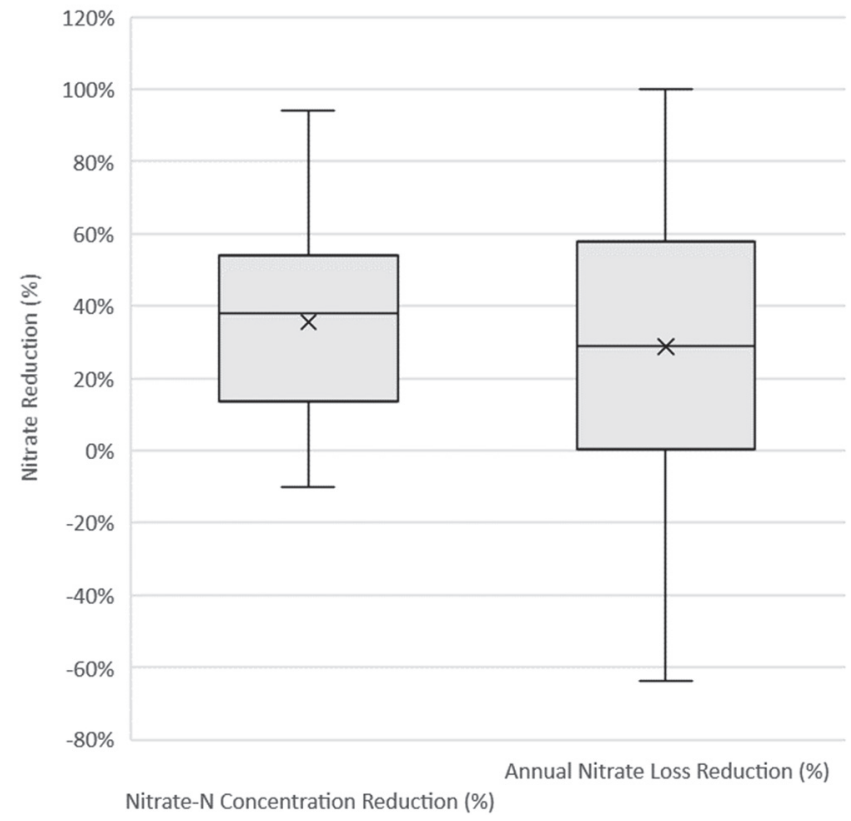

(b)

Figure 4. (a) Nitrate-N concentration reduction efficiency related to nitrate-N loss reduction efficiency, including all studies reporting both concentration and losses in water (number of observations $=58$ ), and $(b)$ concentration $(n=58)$ and loss reduction $(n=84)$ distribution of non-legume cover crops. There was no statistically significant difference in means (two-sample t-test assuming equal variances). Data from the study site-years in the U.S. with references and additional details are provided in the Supplemental Material.

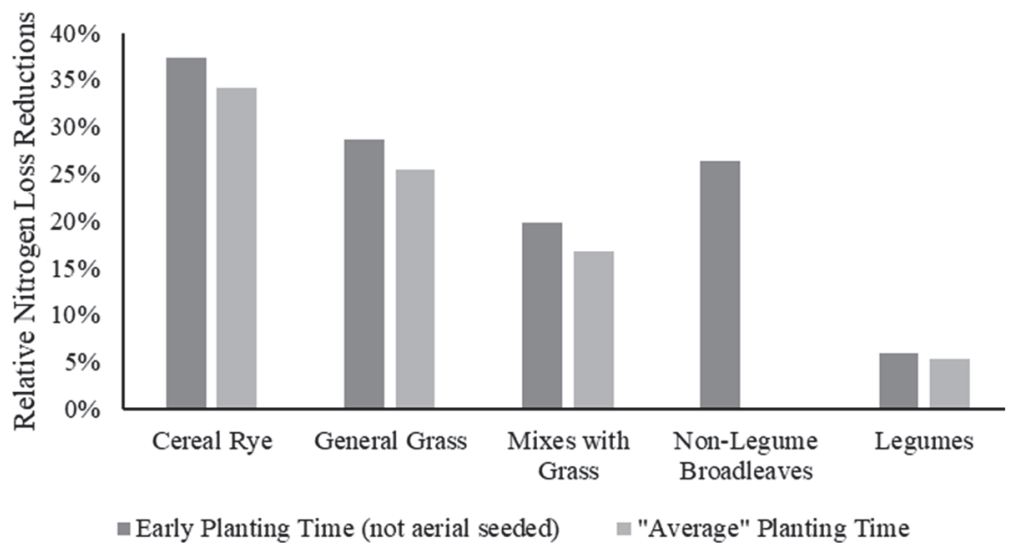

Figure 5. Impact of cover type and crop seeding time on nitrogen reduction. Data are aggregated based on CAST documentation (CAST, 2017). The "general grass" category includes cereal rye along with barley, wheat, and winter hearty oats.

reductions in phosphorus concentration and loss due to cover crop addition were $53 \%$ and $55 \%$, respectively (Daigh et al., 2015 ), although the annual ranges were between $19 \%$ and $88 \%$ for concentration reduction and $-35 \%$ to $93 \%$ for loss reduction. In surface runoff, Zhu et al. (1989) found substantial increases (from $61 \%$ to $186 \%$ ) in orthophosphate concentration due to a cover crop; however, because runoff volumes were less, loss reductions of $7 \%$ to $63 \%$ were found. The average dissolved phosphorus fraction of total phosphorus in the review by Liu et al. (2019) was between 35\% and $40 \%$ for runoff and about $25 \%$ for subsurface drainage, neither of which were significantly different from the phosphorus loss fractions from bare soils.

\section{Total PhOSPhORus}

Kaspar et al. (2008) found high phosphorus loss reductions (54\% to $94 \%$ ) due to cover crop use in a range of geographic locations in the U.S. In contrast, the nutrient reduction strategies for states in the Mississippi River basin, ranging from Minnesota to Arkansas, used much lower phosphorus loss reduction values of about $30 \%$ for statewide accounting (FTN Associates, 2019; IDALS/IDNR/ISU, 2016; IEPA/IDOA, 2015; MPCA, 2014). The loss reduction values for the Mississippi River basin were primarily based on literature reviews. Lower still were estimates for the Chesapeake Bay region, where the Chesapeake Assessment Scenario Tool (CAST) showed phosphorus loss reductions between $3 \%$ and $15 \%$, depending on cover crop type and planting time. For example, with early planting, cereal rye, barley, or wheat provided a $15 \%$ phosphorus loss reduction compared to non-legume broadleaves $(10 \%)$, mixes $(9 \%)$, and legumes $(6 \%)$ (CAST, 2017). The phosphorus loss reduction estimates for normal planting times excluded nonlegume broadleaves due to their limited fall growth when not 
planted early and showed phosphorus loss reductions of $7 \%$, $5 \%$, and $3 \%$ for cereal rye/barley/wheat, mixes, and legumes, respectively (CAST, 2017). These estimates from the Chesapeake Bay Expert Panel process were the only source of information distinguishing between different types of cover crops for total phosphorus loss reduction and are summarized in figure 6.

The review by Liu et al. (2019) showed no significant reduction in total phosphorus loss from runoff, although they found a slight but statistically significant increase in total phosphorus loss in leaching from topsoil. However, the losses from topsoil did not result in significant differences in total phosphorus loss from tile drainage. In a review focusing on Scandinavian countries, Aronsson et al. (2016) commented on the limited benefit of cover crops, when compared to other conservation practices such as reduced tillage, for reducing phosphorus in areas where substantial mitigation of erosion is not needed. Liu et al. (2019) also noted that phosphorus losses in areas with erodible soils can be substantially reduced when using a cover crop due to the higherrisk landscape. An example of a higher-risk landscape was included in a Missouri study incorporating terraces and notill to reduce erosion losses (Adler et al., 2020). In their study, Adler et al. (2020) found that cover crops reduced total phosphorus losses by more than $50 \%$, which mirrored the total suspended sediment losses. Several studies have found reductions in sediment losses or erosion due to a cover crop (Kaspar et al., 2001; Langdale et al., 1991; Mutchler and McDowell, 1990; Zhu et al., 1989) with a range from $0 \%$ to $100 \%$ reduction (of the measured sediment parameter) and a mean of $44 \%$. These studies tended to have land slopes of greater than $3 \%$, potentially making erosion a concern for environmental and production quality.

Based on these findings, it is clear that research is lacking on long-term annual phosphorus loss reduction due to cover crop implementation. Further, a substantial gap seems to exist in documenting the annual impact of cover crop implementation in varying landscapes. This includes differences between low and high stormwater runoff potential and erosion-prone landscapes. Although not fully explored here, sediment and erosion research could likely serve as an example and maybe a proxy for the impact of cover crop implementation on total phosphorus losses.

\section{COST-EFFEctiveness}

Performance-based cost ranges are extensive due to the vast number of estimation techniques, geographic settings, assumptions, and measurement locations associated with nutrient and sediment loss reductions. For example, measures of pollutant mass loss reduction tend to be based on monitoring at the edge of the field, which is not helpful when considering transport through a larger watershed, where pollutants are subject to physical and biological processes. In the Chesapeake Bay region, delivery ratios compensate for this discrepancy, with discounts applied to edge-of-field estimates or measurements of processes occurring between the location of generation and the area of interest (e.g., outlet of a watershed). With these points in mind, development of this metric adds confusion to the selection and comparison of conservation practices when done outside of a common framework or model. The use of a cost-per-hectare-treated metric along with a relative loss reduction (\%) allows direct comparisons of conservation practices.

The costs of conservation practices have been evaluated using previously completed economic assessments relating to a cereal rye cover crop. Roley et al. (2016) evaluated multiple data sources throughout the U.S. Corn Belt (Iowa, Illinois, Indiana, and Ohio) and separated costs into categories including seed purchase, planting, termination, and change in cropping system management. Due to conflicting research, impacts on yield were ignored by Roley et al. (2016). Their evaluation focused on cereal rye due to the nitrogen loss reductions associated with this cover crop in the Corn Belt states. The results from Roley et al. (2016) indicated a cost of $\$ 151 \mathrm{ha}^{-1}$ year-1, with a range of $\$ 140 \mathrm{ha}^{-1}$ year ${ }^{-1}$ to $\$ 162 \mathrm{ha}^{-1}$ year $^{-1}$. Approximately $70 \%$ of the cost was cover crop establishment, with management being the remainder.

There have been recent efforts in Illinois, Iowa, and Minnesota (IDALS/IDNR/ISU, 2016; IEPA/IDOA, 2015; MPCA, 2014) to address nitrogen and phosphorus losses to the Gulf of Mexico. These efforts included evaluations of cover crop costs. The assumptions included in each strategy differ, although estimated costs range from $\$ 71.70 \mathrm{ha}^{-1}$ year $^{-1}$ in Illinois to $\$ 131$ ha $^{-1}$ year-1 in Minnesota, with Iowa showing a range of $\$ 111 \mathrm{ha}^{-1}$ year-1 to $\$ 121 \mathrm{ha}^{-1}$ year ${ }^{-1}$. In addition to differences in cost assumptions, each state had its own method for estimating nitrogen and phosphorus loads and the

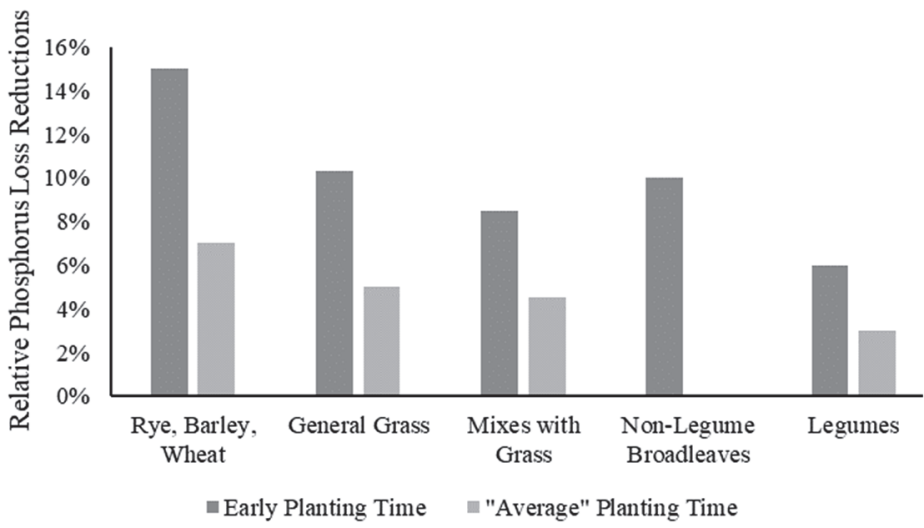

Figure 6. Impact of cover crop type and seeding time on phosphorus reduction. Data are aggregated based on Chesapeake Assessment Scenario Tool (CAST) documentation (CAST, 2017). The "general grass" category includes cereal rye along with triticale and winter hearty oats. 
Table 1. Summarized cost-effectiveness of cover crop implementation. Cropping systems noting a year represent use of a cover crop continuously for that period. Negative values indicate cost savings due to savings on fertilizer, weed control, erosion repair, and yield increases.

\begin{tabular}{ccccc}
\hline & & \multicolumn{3}{c}{ Cost Range (means shown in parentheses) } \\
\cline { 3 - 5 } Reference & Cropping System & $\$$ ha $^{-1}$ year $^{-1}$ & $\$ \mathrm{~kg}^{-1} \mathrm{~N} \mathrm{year}^{-1}$ & - \\
\hline Roley et al. (2016) & Corn/soybean & 140 to 162 (151) & - & - \\
\hline IDALS/IDNR/ISU (2016) & Corn/soybean & 111 to 121 (116) & 2.70 & 27.20 to 68 (47.60) \\
\hline IEPA/IDOA (2015) & Corn/soybean & 71.70 & 1.50 to 5.00 (3.25) & 11.10 to 59.20 (35.15) \\
\hline MPCA (2014) & Corn/soybean & 131 & - & - \\
& Corn/soybean & 37 to 193 (91) & - & - \\
& Corn year 1 & 77 & - & - \\
Myers et al. (2019) & Corn year 3 & -3.50 & - & - \\
& Corn year 5 & -44 & - & - \\
& Soybean year 1 & 58 & - & - \\
& Soybean year 3 & -1.00 & - & - \\
\hline
\end{tabular}

load reductions associated with land use management and cover crop implementation. These differences limit the value of comparing costs on a mass reduction scale, although within a given framework (e.g., a state-level strategy), this type of comparison to other conservation options is helpful. The Illinois and Iowa strategies reported costs ranging from $\$ 1.50 \mathrm{~kg}^{-1}$ year ${ }^{-1}$ to $\$ 5.00 \mathrm{~kg}$ year ${ }^{-1}$ for nitrogen and from $\$ 27.20 \mathrm{~kg}^{-1}$ year ${ }^{-1}$ to $\$ 68.00 \mathrm{~kg}$ year ${ }^{-1}$ for phosphorus.

Generally, cover crops have been evaluated based on input costs; however, Myers et al. (2019) used national cover crop survey data (CTIC, 2013, 2017), including costs and benefits of a cover crop, to develop a more comprehensive accounting. Their assessment included seed, seeding, and termination, with a range of $\$ 37 \mathrm{ha}^{-1}$ year ${ }^{-1}$ to $\$ 193 \mathrm{ha}^{-1}$ year $^{-1}$, which encompasses the ranges found in previous work. The median value was $\$ 91 \mathrm{ha}^{-1}$ year $^{-1}$, which was used for subsequent assessment. Additionally, Myers et al. (2019) evaluated economic benefits at one, three, and five years of using a cover crop. The assessment was divided into savings on fertilizer, weed control, and erosion repair, as well as survey-reported increases in yield. The results were separated by corn and soybeans, with a cover crop before corn costing about $\$ 77 \mathrm{ha}^{-1}$ year $^{-1}$ in year 1 , with positive economic returns in years 3 and

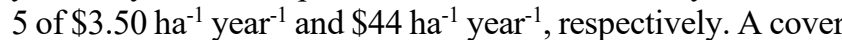
crop before soybeans cost about $\$ 58 \mathrm{ha}^{-1}$ year $^{-1}$ in year 1 , with positive economic returns in years 3 and 5 of $\$ 1 \mathrm{ha}^{-1}$ year $^{-1}$ and $\$ 25 \mathrm{ha}^{-1}$ year $^{-1}$, respectively. These costs as well as state-level costs are summarized in table 1 .

\section{MONITORING RECOMMENDATIONS}

The majority of previous research has focused on the water quality benefits of a cereal rye cover crop. Cereal rye has been the primary cover crop planted, although there is increasing use of seed mixes (CTIC, 2017). Research on the impact of cover crop mixes on water quality is needed to mirror this trend. Further, because one of the primary benefits of a cover crop, as noted by farmers, is improved soil health (CTIC, 2017), there is a secondary need to link specific soil health metrics and general improved soil health with resulting water quality. Establishing these links will require well-designed, focused, and long-term studies directly measuring both soil health metrics and water quality.

The techniques used to monitor the water quality benefits of cover crops vary substantially due to different landscapes and the evolution of monitoring methods. For example, in landscapes with subsurface tile drainage, very little runoff occurs, and monitoring focuses on the subsurface tile drainage systems, while areas with topographic relief require surface runoff monitoring. Ultimately, the monitoring setup must conform to the needs of each site and be designed to measure the specific objectives of the study. The monitoring setup should also be representative of the spatial scale (e.g., edge-of-field or watershed) and the time associated with the study (e.g., event-based, seasonal, annual, or long-term).

Standard reporting metrics are difficult to determine for cover crop research due to the integrated nature of the practice with many agronomic management activities (e.g., tillage, nutrient management, water management, etc.). Studies focusing on water quality should, at a minimum, report the information contained in table 2 .

\section{CONCLUSION}

There are many more avenues to pursue when considering how to enhance the effectiveness of cover crops to reduce nitrogen and phosphorus losses from agricultural

Table 2. Suggested information to report for cover crop studies focusing on water quality.

\begin{tabular}{|c|c|}
\hline Parameter & Rational for Inclusion \\
\hline Cropping system & Allows comparison between similar settings. \\
\hline Years of study & Allows consideration of climate drivers. \\
\hline $\begin{array}{c}\text { Location } \\
\text { (i.e., state or county) }\end{array}$ & $\begin{array}{l}\text { Allows consideration of geographic factors } \\
\text { when evaluating cover crops. }\end{array}$ \\
\hline Type of cover crop & Includes specific information about mix ratios. \\
\hline $\begin{array}{l}\text { Planting and } \\
\text { termination dates }\end{array}$ & $\begin{array}{l}\text { These dates are linked to plant growth and } \\
\text { can be used with biomass to refine cover } \\
\text { crop management. }\end{array}$ \\
\hline Planting method & $\begin{array}{l}\text { Planting method can impact germination } \\
\text { and establishment density. }\end{array}$ \\
\hline Generated biomass & $\begin{array}{l}\text { Cover crop performance (especially nitrate } \\
\text { loss reduction) has been linked to increased } \\
\text { biomass growth. }\end{array}$ \\
\hline $\begin{array}{c}\text { Landscape } \\
\text { characteristics }\end{array}$ & $\begin{array}{l}\text { Landscape characteristics (including surface } \\
\text { and subsurface drainage patterns) influence } \\
\text { the processes acting on pollutants. }\end{array}$ \\
\hline Soil characteristics & $\begin{array}{l}\text { There may be an emerging trend showing } \\
\text { increased nitrate loss reduction effectiveness } \\
\text { in coarse or medium textured soils. }\end{array}$ \\
\hline Soil organic matter & $\begin{array}{l}\text { Mineralization may dominate nitrate loss } \\
\text { in soils with high soil organic matter. }\end{array}$ \\
\hline Pollutants evaluated & For comparison with other research. \\
\hline $\begin{array}{c}\text { Absolute annual } \\
\text { pollutant loss reduction }\end{array}$ & $\begin{array}{c}\text { Absolute values depend on monitoring } \\
\text { location (e.g., edge-of-field or watershed). }\end{array}$ \\
\hline $\begin{array}{c}\text { Relative annual } \\
\text { pollutant loss reduction }\end{array}$ & $\begin{array}{l}\text { Relative loss reductions can be scaled to } \\
\text { match multiple applications. }\end{array}$ \\
\hline
\end{tabular}


landscapes. Future investigations could range from streamlining cover crop management (increased seeding rate, earlier planting date, later termination date) to selecting appropriate species to achieve water and soil quality goals. Despite these gaps and the potential enhancements resulting from filling these gaps, implementation of cover crops across the country will be a significant component of strategies to improve water quality.

For reducing nutrient losses from agricultural landscapes to receiving water bodies, over-wintering grasses tend to be the most beneficial. Many grasses survive the winter months, which allows production of more biomass. With increasing biomass production, immobilization of nitrogen into that biomass increases, as does groundcover to protect the soil from erosion and phosphorus losses. Reductions in nitrate loss range from $-64 \%$ to $100 \%$ for non-legumes (primarily grasses). The latest cover crop review found an average nitrate loss reduction of $56 \%$, with prior reviews finding loss reductions between $50 \%$ and $70 \%$. In the U.S.-specific literature reviewed here, there was a site-year mean and median nitrate- $\mathrm{N}$ loss reduction of $29 \%$ when considering studies measuring water quality and using non-legumes. When this was aggregated to treatments in individual studies (often over multiple years), the mean and median nitrate loss reductions were $40 \%$ and $36 \%$, respectively. Cover crop effectiveness tended to decrease from south to north in the U.S. Reductions in total nitrogen loss were less clear due to limited data, although cereal rye provided the largest water quality benefits, and legumes provided the lowest.

Few studies considered the annual phosphorus (dissolved or total) loss reductions of cover crops. Generally, cover crops were more beneficial for reducing total phosphorus loss in areas at risk for erosion. Dissolved phosphorus losses can increase as freeze-thaw cycles become more frequent or harsher. Dissolved phosphorus tends to be mitigated by the sorption potential of underlying soils, and this is an area of active investigation.

Cover crop mixes with grasses, legumes, and brassicas are becoming more popular due to their ancillary benefits, including biological fixation of nitrogen. While mixes tend not to provide as much nutrient loss reduction as grasses, there is potential for a nitrogen credit to the subsequent crop, especially if legumes are present. Further, all the nitrogen immobilized in biomass will become available for future crop use, although questions remain about the timing of that availability.

\section{SUPPLEMENTAL MATERIAL}

The Supplemental Material, available at https://doi.org/10.13031/14519094.v1, provides additional information that may not have explicitly been referenced in this article. These additional data add substance to the discussion and are intended to add transparency. The spreadsheet includes U.S.-specific studies reporting total nitrogen, nitrate, total phosphorus, phosphate, and sediment or erosion concentrations or losses from control and cover crop field plot studies. Where pertinent data were not reported in tabular format, DataThief software was used (Tummers, 2006). Some aggregation was done on these data to appropriately bin them into grass, legume, brassica, and mixed categories, based on the type of cover crop evaluated. Further loss reduction calculations were done based on reported concentrations or losses from the literature reviewed in a site-year approach, where possible. Because of this, the resulting percent loss reductions reported here may be slightly different from those reported in the original source.

Further, each study was aggregated to a study component average (e.g., legume treatment, which may have included more than one type of legume) in an attempt to represent the study findings while reducing the variability associated with the site-year approach. These data were used to develop a series of correlations to evaluate trends associated with cover crop use in the U.S. to support Conservation Practice Standard 340. Data not reported by a given study were left blank, and calculations based on missing data were represented with \#N/A. Table S1 summarizes the site-year data provided in the Supplemental Material.

\section{ACKNOWLEDGEMENTS}

Content included in this study was supported in part by historic funding from the Walton Family Foundation. The authors would additionally like to thank the U.S. Environmental

Table S1. Summarized site-year data as well as state or basin-wide efforts. Complete data are provided in the Supplemental Material.

\begin{tabular}{|c|c|c|c|c|c|c|c|}
\hline \multirow[b]{2}{*}{ Cover Crop Type } & \multirow[b]{2}{*}{$\begin{array}{c}\text { No. of } \\
\text { Site-Years }\end{array}$} & \multirow[b]{2}{*}{ Pollutant } & \multicolumn{5}{|c|}{ Reduction in Mass (\%) } \\
\hline & & & Mean $^{[\mathrm{a}]}$ & Maximum & Minimum & $\begin{array}{c}25 \text { th } \\
\text { Percentile }\end{array}$ & $\begin{array}{c}\text { 75th } \\
\text { Percentile }\end{array}$ \\
\hline Aggregated & $n=25$ & Sediment or erosion & 73 & 100 & 0 & 54 & 95 \\
\hline \multirow[t]{3}{*}{ General grass } & $n=72$ & Nitrate-nitrogen (total $\mathrm{N}$ ) & $26(25)$ & 100 & -64 & 0 & 55 \\
\hline & $n=2$ & Dissolved phosphorus (total P) & 24 & 41 & 7 & - & - \\
\hline & $n=12$ & Sediment or erosion & 96 & 100 & 90 & 94 & 100 \\
\hline \multirow[t]{3}{*}{ Mixed with grass } & $n=11$ & Nitrate-nitrogen (total $\mathrm{N}$ ) & $40(17)$ & 74 & -13 & 21 & 63 \\
\hline & - & Dissolved phosphorus (total P) & $(5)$ & - & - & - & - \\
\hline & $n=3$ & Sediment or erosion & 55 & 63 & 42 & 51 & 61 \\
\hline \multirow[t]{3}{*}{ Non-legume broadleaves } & $n=1$ & Nitrate-nitrogen (total $\mathrm{N}$ ) & $77(0)$ & - & - & - & - \\
\hline & $n=1$ & Dissolved phosphorus (total P) & 63 & - & - & - & - \\
\hline & $n=3$ & Sediment or erosion & 89 & 92 & 83 & 87 & 92 \\
\hline \multirow[t]{3}{*}{ Legumes } & $n=3$ & Nitrate-nitrogen (total N) & $46(5)$ & 56 & 28 & 41 & 56 \\
\hline & - & Dissolved phosphorus (total P) & (3) & - & - & - & - \\
\hline & $n=1$ & Sediment or erosion & 5 & - & - & - & - \\
\hline \multirow[t]{2}{*}{ Rye } & $n=58$ & Nitrate-nitrogen (total $\mathrm{N}$ ) & $23(34)$ & 100 & -64 & -4 & 56 \\
\hline & $n=4$ & Dissolved phosphorus (total P) & $29(7)$ & 93 & -35 & 6 & 53 \\
\hline \multicolumn{2}{|c|}{ Grass, nutrient reduction strategies ${ }^{[\mathrm{b}]}$} & Total P & 30 & - & - & - & - \\
\hline
\end{tabular}

[a] Values in parentheses are information from CAST (2017).

[b] Information from Arkansas, Illinois, and Iowa Nutrient Strategies (FTN Associates, 2019; IEPA/IDOA, 2015; IDALS/IDNR/ISU, 2016). 
Protection Agency and the American Society of Agricultural and Biological Engineers for hosting this special collection.

\section{REFERENCES}

Abdollahi, L., \& Munkholm, L. J. (2014). Tillage system and cover crop effects on soil quality: I. Chemical, mechanical, and biological properties. SSSA J., 78(1), 262-270. https://doi.org/10.2136/sssaj2013.07.0301

Adler, R. L., Singh, G., Nelson, K. A., Weirich, J., Motavalli, P. P., \& Miles, R. J. (2020). Cover crop impact on crop production and nutrient loss in a no-till terrace topography. J. Soil Water Cons., 75(2), 153-165. https://doi.org/10.2489/jswc.75.2.153

Al-Kaisi, M. M., Yin, X., \& Licht, M. A. (2005). Soil carbon and nitrogen changes as influenced by tillage and cropping systems in some Iowa soils. Agric. Ecosyst. Environ., 105(4), 635-647. https://doi.org/10.1016/j.agee.2004.08.002

Alliaume, F., Rossing, W. A., Tittonell, P., Jorge, G., \& Dogliotti, S. (2014). Reduced tillage and cover crops improve water capture and reduce erosion of fine-textured soils in raised bed tomato systems. Agric. Ecosyst. Environ., 183, 127-137. http://dx.doi.org/10.1016/j.agee.2013.11.001

Aronsson, H., Hansen, E., Thomsen, I. K., Liu, J., Øgaard, A. F., Känkänen, H., \& Ulén, B. (2016). The ability of cover crops to reduce nitrogen and phosphorus losses from arable land in southern Scandinavia and Finland. J. Soil Water Cons., 71(1), 41-55. https://doi.org/10.2489/jswc.71.1.41

Aryal, N., Reba, M. L., Straitt, N., Teague, T. G., Bouldin, J., \& Dabney, S. (2018). Impact of cover crop and season on nutrients and sediment in runoff water measured at the edge of fields in the Mississippi Delta of Arkansas. J. Soil Water Cons., 73(1), 24-34. https://doi.org/10.2489/jswc.73.1.24

Brinsfield, R. B., \& Staver, K. W. (1991). Use of cereal grain cover crops for reducing groundwater nitrate contamination in the Chesapeake Bay region. Soil Water Cons. Soc., 79-82.

Bullard, W. E. (1966). Effects of land use on water resources. $J$. Water Polluti. Control Fed., 645-659.

CAST. (2017). CAST documentation: Source data. Annapolis, MD: Chesapeake Bay Program. Retrieved from https://cast.chesapeakebay.net/Home/SourceData

Christianson, R., Christianson, L., Wong, C., Helmers, M., McIsaac, G., Mulla, D., \& McDonald, M. (2018). Beyond the nutrient strategies: Common ground to accelerate agricultural water quality improvement in the upper Midwest. J. Environ. Mgmt., 206, 1072-1080. https://doi.org/10.1016/j.jenvman.2017.11.051

CTIC. (2013). Report of the 2013-2013 National Cover Crop Survey. West Lafayette, IN: Conservation Technology Information Center. Retrieved from https://www.sare.org/content/download/70390/998785/SARECTIC CC Survey_Report V2.8.pdf?inlinedownload $=1$

CTIC. (2017). Report of the 2016-2017 National Cover Crop Survey. West Lafayette, IN: Conservation Technology Information Center. Retrieved from https://www.sare.org/content/download/79876/1402074/20162017_Cover_Crop_Survey_Report.pdf?inlinedownload=1

Dabney, S. M., Delgado, J. A., \& Reeves, D. W. (2001). Using winter cover crops to improve soil and water quality. Commun. Soil Sci. Plant Anal., 32(7-8), 1221-1250. https://doi.org/10.1081/CSS-100104110

Daigh, A. L., Zhou, X., Helmers, M. J., Pederson, C. H., Horton, R., Jarchow, M., \& Liebman, M. (2015). Subsurface drainage nitrate and total reactive phosphorus losses in bioenergy-based prairies and corn systems. J. Environ. Qual., 44(5), 1638-1646. https://doi.org/10.2134/jeq2015.02.0080
De Baets, S., Poesen, J., Meersmans, J., \& Serlet, L. (2011). Cover crops and their erosion-reducing effects during concentrated flow erosion. Catena, 85(3), 237-244. https://doi.org/10.1016/j.catena.2011.01.009

Ding, G., Liu, X., Herbert, S., Novak, J., Amarasiriwardena, D., \& Xing, B. (2006). Effect of cover crop management on soil organic matter. Geoderma, 130(3-4), 229-239. https://doi.org/10.1016/j.geoderma.2005.01.019

Dougherty, B. W., Pederson, C. H., Mallarino, A. P., Andersen, D. S., Soupir, M. L., Kanwar, R. S., \& Helmers, M. J. (2020). Midwestern cropping system effects on drainage water quality and crop yields. J. Environ. Qual., 49(1), 38-49. https://doi.org/10.1002/jeq2.20007

Finney, D. M., White, C. M., \& Kaye, J. P. (2016). Biomass production and carbon/nitrogen ratio influence ecosystem services from cover crop mixtures. Agron. J., 108(1), 39-52. https://doi.org/10.2134/agronj15.0182

FTN Associates. (2019). Arkansas nutrient reduction measurement framework: Nutrient reduction efficiencies for selected agricultural management practices. Little Rock, AR: Arkansas Natural Resources Commission.

Hagen, S., Cooke, I., Watts, C., Scanlon, K., Towery, D., \& Salas, W. (2016). Operational Tillage Information System (OpTIS): A pilot demonstration project mapping tillage practice and winter cover crops annually across the state of Indiana between 2006 and 2015. West Lafayette, IN: Conservation Technology Information Center. Retrieved from http://optis.ags.io/documents/47/OPTIS_201701.pdf

Helmers, M., \& Crumpton, W. (2015). Water and nutrient research: In-field and offsite strategies (presentation). Des Moines, IA: Iowa Department of Agriculture and Land Stewardship.

Hively, W. D., Lang, M., McCarty, G. W., Keppler, J., Sadeghi, A., \& McConnell, L. L. (2009). Using satellite remote sensing to estimate winter cover crop nutrient uptake efficiency. J. Soil Water Cons., 64(5), 303-313. https://doi.org/10.2489/jswc.64.5.303

Hypoxia Task Force. (2017). Mississippi River/Gulf of Mexico Watershed Nutrient Task Force: 2017 Report to Congress. Washington, DC: U.S. Environmental Protection Agency. Retrieved from https://www.epa.gov/sites/production/files/201711/documents/hypoxia_task_force_report_to_congress_2017_fi nal.pdf

IDALS/IDNR/ISU. (2016). Iowa nutrient reduction strategy: A science and technology-based framework to assess and reduce nutrients to Iowa waters and the Gulf of Mexico. Ames, IA: Iowa Department of Agriculture and Land Stewardship, Iowa Department of Natural Resources, and Iowa State University College of Agriculture and Life Sciences. Retrieved from http://www.nutrientstrategy.iastate.edu/sites/default/files/docum ents/INRSfull-161001.pdf

IEPA/IDOA. (2015). Illinois nutrient loss reduction strategy. Springfield, IL: Illinois Environmental Protection Agency and Illinois Department of Agriculture.

Kaspar, T. C., \& Singer, J. W. (2011). The use of cover crops to manage soil. In J. L. Hatfield \& T. J. Sauer (Eds.), Soil management: Building a stable base for agriculture (pp. 321337). Madison, WI: ASA, SSSA.

Kaspar, T. C., Jaynes, D. B., Moorman, T. B., \& Parkin, T. B. (2003). Reducing nitrate levels in subsurface drain water with organic matter incorporation. Ames, IA: USDA-ARS National Soil Tilth Laboratory.

Kaspar, T. C., Jaynes, D. B., Parkin, T. B., \& Moorman, T. B. (2007). Rye cover crop and gamagrass strip effects on $\mathrm{NO}_{3}$ concentration and load in tile drainage. J. Environ. Qual., 36(5), 1503-1511. https://doi.org/10.2134/jeq2006.0468 
Kaspar, T. C., Kladivko, E. J., Singer, J. W., Morse, S., \& Mutch, D. R. (2008). Chapter 10: Potential and limitations of cover crops, living mulches, and perennials to reduce nutrient losses to water sources from agricultural fields in the upper Mississippi River basin. In Final Report: Gulf hypoxia and local water quality concerns workshop (pp. 129-148). St. Joseph, MI: ASABE.

Kaspar, T. C., Radke, J. K., \& Laflen, J. M. (2001). Small grain cover crops and wheel traffic effects on infiltration, runoff, and erosion. J. Soil Water Cons., 56(2), 160-164.

Kaye, J., Finney, D., White, C., Bradley, B., Schipanski, M., Alonso-Ayuso, M., ... Mejia, C. (2019). Managing nitrogen through cover crop species selection in the US mid-Atlantic. PLoS One, 14(4), e0215448. https://doi.org/10.1371/journal.pone.0215448

Kuo, S., \& Sainju, U. M. (1998). Nitrogen mineralization and availability of mixed leguminous and non-leguminous cover crop residues in soil. Biol. Fertil. Soils, 26(4), 346-353. https://doi.org/10.1007/s003740050387

Kuo, S., Huang, B., \& Bembenek, R. (2001). Effect of winter cover crops on soil nitrogen availability, corn yield, and nitrate leaching. Sci. World J., 1, article 798427. https://doi.org/10.1100/tsw.2001.267

Langdale, G., Blevins, R. L., Karlen, D. L., McCool, D. K., Nearing, M. A., Skidmore, E. L., ... Williams, J. R. (1991). Cover crop effects on soil erosion by wind and water. In Cover crops for clean water (pp. 15-22). Ankeny, IA: Soil and Water Conservation Society.

Liu, J., Macrae, M. L., Elliott, J. A., Baulch, H. M., Wilson, H. F., \& Kleinman, P. J. (2019). Impacts of cover crops and crop residues on phosphorus losses in cold climates: A review. $J$. Environ. Qual., 48(4), 850-868. https://doi.org/10.2134/jeq2019.03.0119

MCCC. (2014). Midwest cover crops field guide. West Lafayette, IN: Purdue University. Midwest Cover Crops Council.

Meisinger, J. J., Hargrove, W. L., Mikkelsen, R. L., Williams, J. R., \& Benson, V. W. (1991). Effects of cover crops on groundwater quality. In Cover crops for clean water (pp. 57-68). Ankeny, IA: Soil and Water Conservation Society.

MPCA. (2014). The Minnesota nutrient reduction strategy. St. Paul: Minnesota Pollution Control Agency. Retrieved from https://www.pca.state.mn.us/sites/default/files/wq-s1-80.pdf

Mutchler, C. K., \& McDowell, L. L. (1990). Soil loss from cotton with winter cover crop. Trans. ASAE, 33(2), 432-436. https://doi.org/10.13031/2013.31347

Myers, R., Weber, A., \& Tellatin, S. (2019). Cover crop economics: Opportunities to improve your bottom line in row crops. College Park, MD: Sustainable Agriculture Research and Education. Retrieved from https://www.sare.org/LearningCenter/Bulletins/Cover-Crop-Economics

Oskamp, J. (1920). Orchard cover crops. West Lafayette, IN: Purdue University Agricultural Experiment Station.

Pederson, C., Helmers, M., Kanwar, R., \& Mallarino, A. (2014). Impact of liquid swine manure application and cover crops on groundwater quality. Ames, IA: Iowa State University. https://doi.org/10.31274/farmprogressreports-180814-683

Prabhakara, K., Hively, W. D., \& McCarty, G. W. (2015). Evaluating the relationship between biomass, percent groundcover, and remote sensing indices across six winter cover crop fields in Maryland, United States. Intl. J. Appl. Earth Obs. Geoinfo., 39, 88-102. http://dx.doi.org/10.1016/j.jag.2015.03.002

Qi, Z., Helmers, M. J., Christianson, R. D., \& Pederson, C. H. (2011). Nitrate-nitrogen losses through subsurface drainage under various agricultural land covers. J. Environ. Qual., 40(5), 1578-1585. https://doi.org/10.2134/jeq2011.0151
Roley, S. S., Tank, J. L., Tyndall, J. C., \& Witter, J. D. (2016). How cost-effective are cover crops, wetlands, and two-stage ditches for nitrogen removal in the Mississippi River basin? Water Resour. Econ., 15, 43-56. https://doi.org/10.1016/j.wre.2016.06.003

Saxton, K. E., \& Rawls, W. J. (2006). Soil water characteristic estimates by texture and organic matter for hydrologic solutions. SSSA J., 70(5), 1569-1578. https://doi.org/10.2136/sssaj2005.0117

Shipley, P. R., Messinger, J. J., \& Decker, A. M. (1992). Conserving residual corn fertilizer nitrogen with winter cover crops. Agron. J., 84(5), 869-876. https://doi.org/10.2134/agronj1992.00021962008400050020x

Snapp, S. S., Swinton, S. M., Labarta, R., Mutch, D. R., Black, J. R., Leep, R., ... O’Neil, K. (2005). Evaluating cover crops for benefits, costs, and performance within cropping system niches. Agron. J., 97(1), 322-332.

Sojka, R. E., Langdale, G. W., \& Karlen, D. L. (1984). Vegetative techniques for reducing water erosion of cropland in the southeastern United States. Adv. Agron., 37, 155-181. https://doi.org/10.1016/S0065-2113(08)60454-X

Staver, K. W., \& Brinsfield, R. B. (1998). Using cereal grain winter cover crops to reduce groundwater nitrate contamination in the mid-Atlantic Coastal Plain. J. Soil Water Cons., 53(3), 230-240.

Stroud Water Research Center. (2020). Model my watershed. Avondale, PA: Stroud Water Research Center. Retrieved from https://wikiwatershed.org/model/

Tetra Tech. (2018). User's guide: Spreadsheet tool for the estimation of pollutant load (STEPL). Ver. 4.4. 90. Pasadena, CA: Tetra Tech, Inc.

Thapa, R., Mirsky, S. B., \& Tully, K. L. (2018). Cover crops reduce nitrate leaching in agroecosystems: A global meta-analysis. $J$. Environ. Qual., 47(6), 1400-1411. https://doi.org/10.2134/jeq2018.03.0107

Tonitto, C., David, M. B., \& Drinkwater, L. E. (2006). Replacing bare fallows with cover crops in fertilizer-intensive cropping systems: A meta-analysis of crop yield and N dynamics. Agric. Ecosyst. Environ., 112(1), 58-72. https://doi.org/10.1016/j.agee.2005.07.003

Tummers, B. (2006). DataThief III. Retrieved from https://datathief.org/

USDA-NASS. (2017). Census of Agriculture. Washington, DC: USDA National Agricultural Statistics Service.

USDA-NRCS. (2014). Cover crop: Code 340. In National handbook of conservation practices. Washington, DC: USDA Natural Resources Conservation Service. Retrieved from https://www.nrcs.usda.gov/Internet/FSE_DOCUMENTS/stelprd b1263176.pdf

Valkama, E., Lemola, R., Känkänen, H., \& Turtola, E. (2015). Meta-analysis of the effects of undersown catch crops on nitrogen leaching loss and grain yields in the Nordic countries. Agric. Ecosyst. Environ., 203, 93-101. https://doi.org/10.1016/j.agee.2015.01.023

Voorhees, J. H. (1915). Variations in soy bean inoculation. Agron. $J ., 7(3), 139-140$. https://doi.org/10.2134/agronj1915.00021962000700030006x

White, C. M., Finney, D. M., Kemanian, A. R., \& Kaye, J. P. (2016). A model-data fusion approach for predicting cover crop nitrogen supply to corn. Agron. J., 108(6), 2527-2540. https://doi.org/10.2134/agronj2016.05.0288

Zhu, J. C., Gantzer, C. J., Anderson, S. H., Alberts, E. E., \& Beuselinck, P. R. (1989). Runoff, soil, and dissolved nutrient losses from no-till soybean with winter cover crops. SSSA J., 53(4), 1210-1214. https://doi.org/10.2136/sssaj1989.03615995005300040037x 